\section{ETHANOLIC COLUMN EXTRACT OF Potentilla fulgens AND THEIR EFFECTS ON BIOCHEMICAL CHANGES IN LIVER FLUKE VECTOR SNAIL Lymnaea acuminata PRADEEP KUMAR ${ }^{1}$}

Department of Zoology, S.G.N. Govt. P.G. College Muhammadabad Gohna Mau, (U.P), India

\begin{abstract}
Parasitic trematodes, Fasciola hepatica, and $F$. gigantica are causes fascioliasis in both livestock and humans. The snail Lymnaea acuminata is an intermediate host of the Fasciola. One of the major preventive steps against fascioliasis in the control of the vector snail $L$. acuminata. Effect of sub-lethal concentration of $\left(20 \%\right.$ and $60 \%$ of $\left.96 \mathrm{~h} \mathrm{LC}_{50}\right)$ column purified fraction of Potentilla fulgens on free amino acid, protein, and nucleic acid (DNA, RNA) levels in nervous tissue of host snail $L$. acuminata were studied. Alteration in the levels of free amino acid, protein, and nucleic acid in nervous tissue was time and concentration-dependent. Withdrawal experiment demonstrates that there was a significant recovery in free amino acid, protein, DNA, and RNA levels in nervous tissues of snail $L$. acuminata were withdrawn from 7 days which treated with 20 and $60 \%$ of $96 \mathrm{~h} \mathrm{LC}_{50}$ for $96 \mathrm{~h}$.
\end{abstract}

KEYWORDS: Potentilla fulgens; Lymnaea acuminata; Amino Acid; Protein; Nucleic Acid; Fascioliasis

Liver fluke (Fasciola hepatica and F. gigantica) causes liver cirrhosis and it is endemic worldwide diseases which caused severe economic loss and affecting a large cattle population and human (Al-Malki and Degheidy, 2013). The freshwater host snail Lymnaea acuminata is an intermediate host of liver fluke which causes fascioliasis among cattle in the eastern part of India (Singh and Agarwal, 1981). The effect of liver fluke can be controlled by the reduction of snail population due to which beak the life cycle of fluke (Kumar and Singh, 2006, Singh et al., 2008, Kumar et al, 2009, Kumar et al., 2011, Kumar et al., 2014, Kumar et al., 2016, Kumar et al., 2018a, Kumar, 2021). Phytochemicals of the plantderived would be an effective tool for selective killing of the intermediate host snail with a minimal adverse effect on the other non-target animal and environment. The dried root powder of medicinal plant Potentilla fulgens and their different organic extracts, column purified fractions are potent molluscicides against snail Lymnaea acuminata (Kumar et al., 2018a), and Indoplanorbis exustus (Kumar et al., 2018b). Their different preparations are also inhibiting the fecundity, hatchability, and survival of the young snail I. exustus (Kumar, 2021). The present study aims is to evaluate the sub-lethal molluscicides of ethanolic column purified fraction of medicinal plant Potentilla fulgens on the endogenous level of free amino acid, protein, and nucleic acid (DNA, RNA) in the nervous tissue of the snail $L$. acuminata.

\section{MATERIALS AND METHODS}

\section{Collection of Adult Snail}

Adult snail L. acuminata $(2.26 \pm 0.25 \mathrm{~cm}$ in length) were collected locally and used as experimental animals from the lakes and low-lying submerged fields in Muhammadabad Gohna, Mau. The snails were acclimatized in the laboratory for $72 \mathrm{~h}$ in dechlorinated tap water at $26 \pm 1{ }^{0} \mathrm{C}$. Batches of 50 snails were kept in glass aquaria containing 6L dechlorinated tap water. Snails were treated according to the method of Singh and Agarwal (1986; 1989). Food was not provided to treated snail during the experiment. The same method had been used in a large number of studies (Singh and Agarwal $1986 ; 1989)$ and there was no mortality in the controls group. The oxygen concentration was normal in control animals as there was no sign of stress oxygen deficiency. The test method was standardized in the laboratory, in which 50 snails/6L water was used, which causes no oxygen stress in test snails (Singh and Agarwal 1986). The $\mathrm{pH}$ of the water was 7.2-7.4 and dissolved oxygen, free carbon dioxide, and bicarbonate alkalinity were 6.47.2, mg/1, 5.1-6.4mg/1, and 104.0-106.0mg/1, respectively. Dead snails were removed immediately from aquaria to avoid any contamination.

Preparation of Root Powder and Column Purifications

The freshly dried root of Potentilla fulgens was procured from the local market in Muhammadabad Gohna, Mau, (UP) India. The dried root of $P$. fulgens was

${ }^{1}$ Corresponding author 
pulverized separately in the electric grinder and the crude powders thus obtained, were then sieved with the help of a fine mesh cloth. These fine powder gradually mixed well in one thousand milliliters of ethanol organic solvent were subjected to silica gel (60-120 mesh, Qualigens Glass) chromatography through a $5 \times 45 \mathrm{~cm}$ glass column. Five-milliliter column fractions eluted with ethanol were collected. Ethanol was evaporated under a vacuum machine and the remaining solids column extract obtained was used sub-lethal (20 and $60 \%$ of $96 \mathrm{~h} \mathrm{LC}_{50}$, Kumar et al., 2018a) concentration for the endogenous level of free amino acids, protein, and nucleic acids in the nervous tissue of L. acuminata.

\section{Exposure of Snail with Sub-Lethal Concentration}

Adult snail L. acuminata were kept and exposed in glass aquaria containing $6 \mathrm{~L}$ dechlorinated tap water. Each aquarium contains 50 snails. The snails were treated with sub-lethal (20 and $60 \%$ of $96 \mathrm{~h} \mathrm{LC}_{50}$ ) concentrations as reported by Kumar et al., (2018a). The control groups of snails were kept in similar laboratory conditions without treatment. Each experiment was replicated at least 6 times for statistical analysis.

\section{Withdrawal of Treated Snail}

To study the effect of withdrawal from treatment, the snails were first exposed to the above doses for $96 \mathrm{~h}$ following which these were transferred to freshwater. This water was changed every $24 \mathrm{~h}$ for the next seven days, after which biochemical parameters were estimated in the nervous tissue of the snail.

\section{Biochemical Estimations}

The biochemical estimation was made in the nervous tissues of the experimental snails. Treated/control snails were removed from the aquaria, nervous tissues were dissected out, the adherent tissue was removed and the organs were put on a filter paper for absorption of water. 20-25 snails had to be dissected to obtain $100 \mathrm{mg}$ of nervous tissue.

\section{Estimation of Amino Acid}

The estimation of total free amino acids was done by the method of Spies (1957). The nervous tissues were homogenized in $96 \%$ ethanol $(10: 1 \mathrm{w} / \mathrm{v})$ in an electrical homogenizer for 5 minutes and centrifuged at $8000 \mathrm{~g}$ for 20 minutes. In $0.1 \mathrm{ml}$ of supernatant, $0.1 \mathrm{ml}$ of distilled water, and $2.0 \mathrm{ml}$ of ninhydrin reagent were added and mixed thoroughly. The reaction mixture was kept in a boiling water bath for exactly 12-15 minutes. Two milliliters of $50 \%$ ethanol were added to the above solution after cooling. A violet colour developed which was measured at $575 \mathrm{~nm}$. Glycine was used to determine the standard curves. Free amino acids have been expressed as $\mu \mathrm{g} / \mathrm{mg}$ tissues.

\section{Estimation of Protein}

Quantitative estimation of protein was made according to the method of Lowry et al., (1951). The nervous tissues were homogenized $(1 \mathrm{mg} / \mathrm{ml}, \mathrm{w} / \mathrm{v})$ in $10 \%$ TCA using an electrical homogenizer for 5 minutes. Standard curves were prepared with different concentrations of bovine serum albumin. Results have been expressed as $\mu \mathrm{g} / \mathrm{mg}$ tissues.

\section{Estimation of Nucleic Acids (DNA, RNA)}

Estimation of nucleic acids (DNA and RNA) was performed by the method of Schneider (1957). Homogenate $(1.0 \mathrm{mg} / \mathrm{ml}, \mathrm{w} / \mathrm{v})$ of nervous tissues was prepared in $5 \% \mathrm{TCA}$ at $90^{\circ} \mathrm{C}$. The result suspension centrifuged $(5000 \mathrm{~g}$ x 20 minutes) and a clear supernatant solution was taken for the nucleic acids estimation. Standard curves were drawn at different concentrations of calf thymus DNA to determine the standard curve. Yeast RNA was used to the determine standard. Results have been expressed as $\mu \mathrm{g} / \mathrm{mg}$ tissue.

\section{Statistical Analysis}

The data have been expressed as mean $\pm \mathrm{SE}$ of at least six replicates. The student's " $t$ " test was applied between controls and treated groups to analyzed significant changes $(p<0.05)$. The two-way analysis of variance was applied to detect the effect of dose and timedependent effect on biochemical parameters (Sokal and Rohlf, 1973).

\section{RESULTS}

Exposure for $24 \mathrm{~h}$ and $96 \mathrm{~h}$ to $20 \%$ and $60 \%$ of 96h LC L $_{50}$ of column purified fraction of root powder of Potentilla fulgens caused significant changes in the endogenous levels of total free amino acids, protein, and nucleic acid in the nervous tissue of snail L. acuminata. The levels of total free amino acids on sub-lethal $20 \%$ and $60 \%$ at $96 \mathrm{~h}$ exposure in nervous tissue were 48.28 $\mu \mathrm{g} / \mathrm{mg}$ and $53.26 \mu \mathrm{g} / \mathrm{mg}$, respectively (Table-1). The exposure of L. acuminata for $96 \mathrm{~h}$ at sub-lethal $(20 \%$ and $60 \%$ of $96 \mathrm{~h}_{50}$ ) the protein levels in nervous tissue was $49.85 \mu \mathrm{g} / \mathrm{mg}$ and $50.23 \mu \mathrm{g} / \mathrm{mg}$, respectively. Likewise, the total DNA levels in the nervous tissue after $96 \mathrm{~h}$ exposure at sub-lethal $20 \%$ and $60 \%$ exposure were 48.13 $\mu \mathrm{g} / \mathrm{mg}$ and $52.21 \mu \mathrm{g} / \mathrm{mg}$, respectively. The exposure of 20 and $60 \%$ of $96 \mathrm{~h} \mathrm{LC}_{50}$ of column purified fractions caused a further decline in the levels of RNA ware 46.13 $\mu \mathrm{g} / \mathrm{mg}$ and $55.26 \mu \mathrm{g} / \mathrm{mg}$, respectively. Seven days after the snails have withdrawn from the $96 \mathrm{~h}(20 \%$ and $60 \%)$ treatment it was found that there was a significant 
recovery in the levels of total free amino acids, protein, and nucleic acid (DNA, RNA) in the nervous tissue of

snail L. acuminata (Table-1).

Table 1: Biochemical changes in snail L. acuminata in the nervous tissue after exposure for $24 \mathrm{~h}, 48 \mathrm{~h}, 72 \mathrm{~h}$, and $96 \mathrm{~h}$ for the level of total protein, amino acids, DNA, and RNA in sub-lethal (20 and 60\%) exposure of $96 \mathrm{~h} \mathrm{LC}_{50}$ of column purified fraction of Potentilla fulgens. In snail the effect of withdrawal for 7 days exposure for $96 \mathrm{~h}$

\begin{tabular}{|c|c|c|c|c|c|c|c|}
\hline \multicolumn{7}{|c|}{ Amino acids, Proteins, DNA and RNA level ( $\mu$ g/mg tissue \#) } \\
\hline \multirow{2}{*}{$\begin{array}{c}\text { Biochemical } \\
\text { estimations }\end{array}$} & \multirow{2}{*}{ Control } & \multicolumn{2}{|c|}{$\mathbf{2 4 h}^{* *}$} & \multicolumn{2}{|c|}{$\mathbf{9 6 h} * *$} & \multicolumn{2}{c|}{$\begin{array}{c}\text { Effect of withdrawal after } \\
7 \text { days }\end{array}$} \\
\cline { 3 - 8 } & & $20 \%$ & $60 \%$ & $20 \%$ & $60 \%$ & $20 \%$ & $60 \%$ \\
\hline Amino acids & $42.31 \pm 1.51$ & $43.04 \pm 0.46^{*}$ & $46.54 \pm 0.51^{*}$ & $48.28 \pm 1.11^{*}$ & $53.26 \pm 0.83^{*}$ & $41.90 \pm 1.22^{+}$ & $48.96 \pm 1.18^{+}$ \\
& $(100)$ & $(101.7)$ & $(108.8)$ & $(114.11)$ & $(125.8)$ & $(99.03)$ & $(115.71)$ \\
\hline Proteins & $38.92 \pm 1.70$ & $40.51 \pm 1.19^{*}$ & $43.26 \pm 1.61^{*}$ & $49.85 \pm 1.20^{*}$ & $50.23 \pm 1.25^{*}$ & $44.12 \pm 1.73^{+}$ & $48.21 \pm 1.29^{+}$ \\
& $(100)$ & $(104.08)$ & $(111.15)$ & $(128.08)$ & $(129.05)$ & $(113.36)$ & $(123.86)$ \\
\hline DNA & $39.32 \pm 0.18$ & $42.60 \pm 0.85^{*}$ & $44.91 \pm 0.35^{*}$ & $48.13 \pm 1.38^{*}$ & $52.21 \pm 0.91^{*}$ & $46.71 \pm 1.26^{+}$ & $50.67 \pm 0.28^{+}$ \\
& $(100)$ & $(108.34)$ & $(114.21)$ & $(122.40)$ & $(132.78)$ & $(118.79)$ & $(128.86)$ \\
\hline RNA & $32.64 \pm 0.62$ & $39.00 \pm 0.41^{*}$ & $41.13 \pm 0.58^{*}$ & $46.13 \pm 0.82^{*}$ & $55.26 \pm 0.73^{*}$ & $41.93 \pm 0.29^{+}$ & $51.01 \pm 0.23^{+}$ \\
& $(100)$ & $(119.48)$ & $(126.01)$ & $(141.32)$ & $(169.30)$ & $(128.46)$ & $(156.28)$ \\
\hline
\end{tabular}

** Kumar et al., (2018a), Values are mean \pm SE of six replicates. Values in parentheses indicate percent change with controls taken as $100 \%$. *- Significantly $(\mathrm{P}<0.05)$ different from controls then student's t-test was applied.

+- Significantly $(\mathrm{P}<0.05)$ different from $20 \%$ and $60 \%$ of the $24 \mathrm{~h}$ and $96 \mathrm{~h}$ treated groups when student's t- test was applied. Two-way analysis of variance demonstrated that, in snails, changes were dose and time-dependent. \#100 mg of nervous tissues were used for each biochemical estimation in snails L. acuminata

\section{DISCUSSION}

Earlier it was reported that the dried root powder, organic extract (ethanol, acetone, methanol, chloroform, and ether), and ethanolic column purified of Potentilla fulgens are a potent source of the molluscicides/anti-reproductive against freshwater snail Lymnaea acuminata and Indoplanorbis exustus (Kumar et al., 2018a; Kumar et al., 2018b; Kumar, 2021b). The present study is the extension of the same work, in which the effects of sub-lethal dose of column purified fraction of root powder of $P$. fulgens are determine on different biochemical parameters have been investigated. Thus levels of total free amino acids, protein, nucleic acids (DNA, RNA) in the nervous tissue have been studied in treated and untreated (control) snail L. acuminata. It is clear from the result section that exposure of $L$. acuminata to sub-lethal doses of column purified fraction of root powder of $P$. fulgens decreases the rate of the total free amino acids, protein, and amino acid (DNA, RNA) levels in the nervous tissue of L. acuminata. Hemalatha et al., (2013) have been reported the ethanolic root extract of $P$. fulgens preventing gastric ulcers in rats due to anthihistaminic and $\mathrm{H}^{+} \mathrm{K}^{+}$-ATPase inhibitory activities. It may be possible that the different active components of $P$. fulgens in the snail body could change the different biochemical parameters. Kumar, (2020) has been reported that the root extract of $P$. fulgens have anthelmintic activity against the sporocyst, redia and cercaria larvae of Fasciola gigantica. Ray et al., (2010) have been reported that the alcoholic extract of dried root powder of $P$. fulgens reduced significantly vital tegumental enzyme activity of acid phosphatase, alkaline phosphatase and adenosine triphosphatase (ATPase) in cestodes parasite Raillietina echinobothrida, and trematodes Gastrothylax crumenifer, respectively. The acid phosphatase, a lysosomal enzyme, Aruna et al., (1979) plays an important role in catabolism pathological necrosis autolysis. $P$. fulgens root extract is rich in polyphenolic components, with the maximum quantity of phenolic tannins (Hemalatha et al., 2013). Jaitak et al., (2010) have been reported the root extract of $P$. fulgens contain a high amount of tannin and flavonoid. The synthesis of protein in any of the tissue can be affected in two ways by a chemical; (I) it either affects the RNA synthesis at the transcription stage or (II) it somehow affects the uptake of amino acids in the polypeptide chain. Both these possibilities may account for the lower protein content in the affected tissue. In the first case, the RNA synthesis would be inhibited resulting in reduced RNA as well protein content. In the second case, only the protein content would be affected (Tariq et al., 1977).

Data emerging from the result section demonstrated that treatment with sublethal dose of column purified fraction of $P$. fulgens, there was a sharp decline in the levels of total free amino acid, protein, DNA, and RNA. The changes, however, in the case of all the treatments were time and dose-dependent. With reduced RNA levels there is bound to be a fall in protein 
levels because of a reduction in the synthesis of new protein. The result section demonstrated that seven days after the snails were withdrawn from $96 \mathrm{~h}$ column purified fraction of $P$. fulgens sub-lethal treatment was found that there was near-complete recovery in the levels of total free amino acids, protein, DNA, and RNA in the nervous tissue of L. acuminata. This finding demonstrates that the effects of the phytochemicals are reversible.

\section{CONCLUSION}

In conclusion, it can be stated that the plantderived phytochemicals cause an effect on the nervous tissue of the snail where it is a decrease in the levels of free amino acids, proteins, DNA, and RNA in the nervous tissue of the host snail L. acuminata.

\section{REFERENCES}

Al-Malki J.S. and Degheidy N.S., 2013. Field evolution of Anthelmintic efficacy of Balanits egyptiaca against Fasciolosis in goats. Global Veterinaria, 10(6): 686-691.

Aruna P., Chetty C.S., Naidu R.C. and Swami K.S., 1979. Acid phosphatase activity in Indian apple snail, Pila globosa (Swainson), during aestivation and starvation stress. Proc. Indian Acad. Sci, 88B: $363-365$

Hemalatha S., Laloo D., Prasad S.K. and Krishnamurthy S., 2013. Gastroprotective activity of ethanolic root extract of Potentilla fulgens Wall. Ex Hook. Journal of Ethnopharmacology, 146: 505-514.

Jaitak V., Kaul V.K., Himlata N., Kumar B., Singh J., Dhar. and Sharma O.P., 2010. New hopane triterpenes and antioxidant constituents from Potentilla fulgens. Net Prod. Commun, 5:156166.

Kumar P. and Singh D.K., 2006. Molluscicidal activity of Ferula asafoetida, Syzygium aromaticum and Carum carvi and their active components against the snail Lymnaea acuminata. Chemosphere, 63: 1568-1574.

Kumar P., 2021a. Molluscicidal efficacy of medicinal plant Solanum surattense against Fasciola vector snail, Lymnaea acuminata, International Journal of Biological Innovations, 3(1):120-126.

Kumar P., 2021b. Effect of medicinal plant Potentilla fulgens against fecundity, hatchability and survival of Fasciola host snail Indoplanorbis exustus. Indian J. Sci. Res, 11(2): 19-24.
Kumar P., Singh V.K. and Singh D.K., 2009. Kinetics of Enzyme inhibition by Active molluscicidal agents ferulic acide, umbelliferone, eugenol and limonene in the nervous tissue of snail Lymnaea acuminata. Phytotherapy Research, 23(2): 172177.

Kumar P., Singh V.K. and Singh D.K., 2011. Bait formulation of molluscicides and their effects on biochemical changes in the ovotestis of snail Lymnaea acuminata (Mollusca; Gastropoda: Lymnaeidae). Rev. Inst. Med. Trop. Sao Paulo, 53(5): 271-275.

Kumar P., Sunita K. and Singh D.K., 2016. In vitro activity of different phytochemicals in binary combinations against Fasciola gigantica. Current Life Sciences, 2(3): 58-63.

Kumar P., Sunita K. and Singh D.K., 2018a. Efficacy of Potentilla fulgens root powder and their different organic extract against fresh water vector snail Lymnaea acuminata. Asian Journal of Animal and Veterinary Advances, 13(1): 30-34.

Kumar P., Sunita K. and Singh D.K., 2018 b. Molluscicidal activity of different organic root extract of Potentilla fulgens against liver fluke vector snail Indoplanorbis exustus. Asian Journal of Animal Science, 12(1): 30-35.

Kumar P., Sunita K., Singh R.N. and Singh D.K., 2020. Fasciola larvae: Anthelmintic activity of medicinal plant Potentilla fulgens against sporocyst, redia and cercaria, Asian Journal of Advances in Research, 3(3): 24-30.

Kumar P., Sunita K., Singh V.K. and Singh D.K., 2014. Fecundity, hatchability and survival of Indoplanorbis exustus fed to bait containing attractant and molluscicides. New York Science Journal, 7(3): 1-5.

Lowry O.H., Rosenbrough N.J., Farr A.L. and Randall R.J., 1951. Protein measurement with folinphenol reagents. J. Biol. Chem., 193: 265275.

Roy B., Swargiary A., Syiem D. and Tandon V., 2010. Potentilla fulgens (Family Rosaceae), a medicinal plant of North-East India: A natural anthelmintic. J. Parasit Dis, 34: 83-88.

Schneider W.C., 1957. Determination of nucleic acid in the tissue pentose analysis. In: Method in Enzymology. (Ed.) S.P. Colowick and N.O. Kaplan. Academic Press. p. 680. 
Singh D.K. and Agarwal R.A., 1986. Piperonyl butoxide synergism with two synthetic pyrethroids against Lymnaea acuminata. Chemosphere, 15: 493498.

Singh D.K. and Agarwal R.A., 1989. Toxicity of piperonyl butoxide- carbaryl synergism on the snail Lymnaea acuminata. International Revue der Gesamten Hydrobiology, 74: 689-699.

Singh O. and Agarwal R.A., 1981. Toxicity of certain pesticides to two economic species of snail in Northern India. J. Econ Entomol, 74: 568-574.

Singh R.N., Kumar P., Singh V.K. and Singh D.K., 2008. Effect of binary combination of deltamethrin+MGK-264 on the levels of phospholipids and lipid peroxidation in the snail Lymnaea acuminata, Chemosphere, 73: 10321035.

Sokal R.R. and Rohlf F.J., 1973. Introduction to Biostatistics, Freeman, W. H. San Franscisco. p. 368.

Spies J.R., 1957. Colorimetric procedure for amino acids In: Methods in Enzymology (Ed.) S.P. Colowick and N.O. Kaplan. Academic Press. p. 464.

Tariq S., Haqqi M. and Usman M.A, 1977. Effect of thiotepa on RNA and total protein synthesis content in testes of albino rats. Indian J. Exper. Biol., 15: 804-805. 